\title{
Microleakage and Anticariogenic Effect of S-PRG Filler-containing Pit and Fissure Sealant
}

Seungwoo Shin, Jongsoo Kim

Department of Pediatric Dentistry, School of Dentistry, Dankook University

\begin{abstract}
Pit and fissure sealant prevents biofilm accumulation, plays a role in forming a barrier to acidic substance made by the bacteria. The Surface reaction-type pre-reacted glass ionomerI(S-PRG) filler was developed in 1999. S-PRG filler releases fluoride continuously and does not decompose under wet conditions. The aim of this study was to test the microleakage and anticariogenic effect to adjacent enamel of S-PRG filler-containing pit and fissure sealant.

Sound premolars and molars were used in this study. A S-PRG filler-containing pit and fissure sealant, Beautisealant ${ }^{\circledR}$ (Shofu, Japan) was used for this experiment, the composite resin sealant Concise $^{\circledR}(3 \mathrm{M}$ ESPE, USA) was used as control. For the microleakage test, all teeth surface were double coated with finger nail varnish, with the exception of a $1.0 \mathrm{~mm}$ window around the restoration margins. The teeth were immersed in $2 \%$ methylene blue solution for 24 hours and then rinsed in tap water. For the anticariogenic effect evaluation, all tooth were immersed in artificial carious solution for 9 days and rinsed with tap water. Each tooth was embedded in orthodontic acrylic rein and subsequently sectioned longitudinally in a bucco-lingual direction with a lowspeed diamond saw. The cut sections were examined using a stereomicroscope.

Differences in microleakage between the two groups were not different significantly. But the S-PRG filler-containing pit and fissure sealant showed higher anticariogenic effect than that of flowable resin sealant.
\end{abstract}

Key words : S-PRG filler, Giomer, Anticariogenic effect, Microleakage

\section{I. 서 론}

치아우식 예방을 위한 방법으로 식이조절, 잇솔질 교습, 불소 이용 그리고 치면열구전색 등이 있다. 이 중 치면열구전색은 치 아 교합면의 열구에 발생하는 우식을 예방하는 효과적인 방법 으로 알려져 있다 ${ }^{11}$. 치면열구전색은 생물막의 축적을 물리적으 로 막아주며 박테리아에 의해 형성되는 산물질에 화학적 장벽 역할을 한다 ${ }^{2}$.

치면열구전색제의 우식 예방효과는 Cueto와 Buonocore ${ }^{3)}$, Gwinnett와 Ripa ${ }^{4}$ 의 연구에 따르면 영구치에서 $91 \sim 99 \%$ 로
다양하게 보고되고 있다.

1924년 Hyatt ${ }^{5)}$ 는 치아 우식의 위험성이 높은 치면열구부위 에 보존적 I 급 와동을 형성 후 아말감으로 충전하는 예방적 치 아 수복술을 소개하였고, Bodecker ${ }^{6}$ 는 열구 밀봉을 위해 열구 를 탐침을 사용해 청소 후 Oxyphosphate cement를 사용하여 전색하였다. 그 후 Bowen ${ }^{7)}$ 이 잘 분해되지 않으며 산부식된 법 랑질에 잘 붙는 Bis-GMA(Bisphenol-A diglycidyl methacrylate)를 합성해 치면열구전색제로 사용하였다.

불소의 사용은 법랑질의 경도를 증가시키고, 경도가 증가되 면 산에 대한 용해도가 감소해 항우식효과를 얻을 수 있기 때문

Corresponding author : Jongsoo Kim

Department of Pediatric Dentistry, School of Dentistry, Dankook University, 119 Dandaero, Dongnamgu, Cheonan, 330-714, Korea

Tel: +82-41-550-0222 / Fax: +82-41-550-0118 / E-mail: jskim@dku.edu

Received July 3, 2013 / Revised August 23, 2013 / Accepted September 7, 2013

※ The present research was conducted by the research fund of Dankook University in 2013. 
에 ${ }^{8-11)}$, 치면열구전색제에 불소를 첨가하여 부가적인 항우식효 과 얻으려는 시도가 계속되어 왔고, 현재 여러 종류의 불소방출 치면열구전색제가 시판되고 있다 ${ }^{12)}$.

이 중 글래스아이오노머 시멘트는 장기간의 불소유리로 인한 법랑질 탈회예방과 수복물 주위 이차우식을 억제하는 작용이 있어서 이차우식이 빈발하는 소아의 수복재로서 광범위하게 사 용되어져 왔지만, 복합레진에 비해 물성과 치질과의 결합력, 심 미성 등이 떨어지고 조작이 불편한 단점들이 보고되었다 ${ }^{12)}$.

1999년 Robert 등흐는 S-PRG(Surface reaction-type pre-reacted glass ionomer) 필러 기술을 개발하였다. S$\mathrm{PRG}$ 필러는 수분 존재 하에서 스스로 분해되지 않으면서, 지 속적으로 불소를 유리한다. 복합레진에 $\mathrm{S}-\mathrm{PRG}$ 필러를 첨가함 으로써 복합레진과 유사한 물성과 글래스아이오너머 시멘트의 불소 방출 능력에 버금가는 광중합형 자이오머가 개발되었다 ${ }^{14)}$. 광중합형 자이오머를 이용한 치면열구전색제의 불소 방출 및 재충전에 관한 비교 연구들이 보고되고 있으나, 자이오머 치면 열구전색제의 항우식 효과에 관한 연구는 부족하다 생각해 본 연구를 시작하게 되었다.

이에 저자는 S-PRG 필러를 포함하는 치면열구전색제의 미 세누출 및 인접 법랑질에 대한 항우식 효과를 기존의 유동성레 진 치면열구전색제와 비교 분석하였다.

\section{II. 연구 재료 및 방법}

\section{1. 연구 재료}

교정 치료를 위해 발거된 소구치, 대구치를 시진과 탐침으로 검사하여 충전물, 파절, 표면 결함이 없고, Soprolife ${ }^{\circledR}$ (Soprolife, USA)를 통해 치아 우식증이 존재하지 않는 소구치 20 개, 대구치 20개를 실험 대상으로 사용하였다. S-PRG 필러 를 함유해 지속적으로 불소를 유리하는 S-PRG 치면열구전색 제인 Beautisealant ${ }^{\circledR}$ (Shofu, Kyoto, Japan)를 실험군으로, 불소가 포함되지 않는 유동성레진 치면열구전색제 Concise $^{\circledR}$ (3M ESPE, USA)를 대조군으로 선정하였다(Table 1).

\section{2. 연구 방법}

\section{1) 시편제작}

불소가 포함되어 있지 않은 퍼미스와 저속 핸드피스의 러버 컵을 이용하여 실험 대상 치아를 세척하였다. 10개의 소구치와 10 개의 대구치에는 S-PRG 치면열구전색제를, 10 개의 소구치 와 10 개의 대구치에는 유동성레진 치면열구전색제를 제조사의
지시에 따라 적용하였다.

시편은 증류수에 넣어 $37^{\circ} \mathrm{C}$, 습도 $100 \%$ 의 항온 항습기에 24 시간 보관 후 $5^{\circ} \mathrm{C}$ 와 $55^{\circ} \mathrm{C}$ 의 수조에서 각각 30 초씩 교대로 500 회의 열순환 시행하였다. 충분한 건조 후 소구치에 한해 치 면열구 전색제 변연에 $1 \mathrm{~mm}$ 를 제외한 치면 전체에 손톱광택제 (Nail varnish)를 2회 도포 후 건조시켰다.

\section{2) 미세누출 실험}

손톱 광택제를 도포한 치아를 $2 \%$ 메틸렌블루용액에 24 시간 담근 후 꺼내어 흐르는 물에 깨끗이 세척해 여분의 색소를 제거 하였다. 색소를 제거한 치아를 교정용 투명레진에 매립 후 주수 하에서 저속절단기를 사용하여 치아 장축에 평행하게 근심과 원심에 협설방향으로 절단 시행하여 각 치아당 2 개의 시편을 제작하였다. 노출된 절단면은 Ovrebo와 Raadal ${ }^{15}$ 의 기준에 따 라 각 절단면에서 관찰된 최고점을 그 치아의 색소침투도로 평 가하였다(Table 2).

\section{3) 인공우식 용액의 제조}

우식용액은 1987년 White 등히이 합성 polymer gel을 이용 해 만든 것을 사용 하였다. 인공 우식 용액은 $50 \mathrm{cc} 1 \mathrm{M}$ 젖산 (Sigma, USA)에 2차 증류수를 첨가하여 $500 \mathrm{cc}$ 로 만들고, 여 기에 $50 \%$ 수산화나트륨 용액 (Sigma, USA)을 첨가하여 $\mathrm{pH}$ 를 5.0으로 조절하였다. 위 용액에 $1.5 \mathrm{~g}$ calcium phosphate tribasic(Sigma, USA)을 첨가하는데, $20 \%$ 염산 용액으로 $\mathrm{pH}$ 가 5.0 을 유지한 상태로 30 분간 교반기에서 용해시켰다. 용 해가 끝난 용액은 여과지에 여과한 후 $1 \% \mathrm{Carbopol}^{\circledR} 907$ stock solution $200 \mathrm{ml}$ 와 $50 \mathrm{cc} 1.0 \mathrm{M}$ 젖산을 첨가하고, 증류 수를 넣어 $1000 \mathrm{cc}$ 보다 조금 적은 양이 되도록 만들었다. 여기 에 $50 \%$ 수산화나트륨 용액을 첨가하여 $\mathrm{pH} 5.0$ 을 맞추었다. 마지막으로 $1000 \mathrm{cc}$ 가 되도록 증류수를 첨가하여 완성시켰다.

4) 항우식 효과 실험

1987년 White 등'6)이 실험에 사용한 방법에 따라 $0.1 \mathrm{M}$ 젖 산에 인산칼슘(Sigma, USA)과 $1 \%$ 카보폴 $907^{\circledR}$ (Noveon

Table 2. Penetration score and criteria of marginal seal

\begin{tabular}{cl}
\hline Score & \multicolumn{1}{c}{ Criteria } \\
\hline 0 & No penetration \\
1 & Penetration down to half of the length of the fissure \\
2 & Penetration extending beyond half the length of the fissure \\
3 & Penetration into underlying fissure \\
\hline
\end{tabular}

Table 1. Composition of sealant

\begin{tabular}{llc}
\hline \multicolumn{1}{c}{ Control $\left(\right.$ Concise $\left.^{\circledR}\right)$} & Experimental (Beautisealant $\left.{ }^{\mathbb{R}}\right)$ \\
\hline \multirow{3}{*}{ Composition } & Etchant : $37 \%$ Phosphoric acid & Primer : Acetone, Distilled water, Carboxylic acid monomer, Phosphoric acid monomer \\
& Liquid : TEGDMA, BIS-GMA & Liquid : S-PRG filler based on fluoroboroaluminosilicate glass, UDMA, TEGDMA, \\
& Micro fumed silica \\
\hline
\end{tabular}


Inc, Ohio, USA)를 첨가한 후 $\mathrm{pH}$ 5.0으로 조절한 인공우식 용액을 제조하였다. 제조된 우식용액을 용기에 나누어 담은 후 준비된 시편을 넣고 밀봉 후 $37^{\circ} \mathrm{C}$ 로 고정된 항온항습기에 9 일 간 보관하여 우식을 유발시켰다. 각각의 시편은 하루에 1 회씩 흔들어 주었다.

우식이 유발된 20 개의 시편을 생리 식염수로 충분히 세척한 다음 시편 절단이 용이하게 교정용 투명레진에 매립하였고 각 각의 치아는 주수 하에서 microtom를 사용하여 치아 장축에 평행하게 협설방향으로 근심, 중앙, 원심 총 3 개로 절단하였고, 절단된 시편은 주수 하에 실리콘 카바이드 페이퍼에서 활택 시 행 후 활택면을 바닥으로 향하게 하여 슬라이드글라스에 부착 시킨 후 시편이 부착된 슬라이드 글라스를 특별히 고안된 기구 에 끼워 반대면을 다시 활택 시행하였다.

5) 편광현미경 관찰 및 우식 병소의 깊이 측정

준비된 시편은 증류수 침적 하에서 디지털 편광현미경 (Nikon eclipse E200, Japan)으로 100 400배율 하에서 관 찰하고 최적의 영상을 컴퓨터에 JPEG 파일 형식으로 저장하였 다. 촬영된 이미지는 영상 분석 프로그램(Able Image Analyser, $\mathrm{USA}$ )에서 조직학적 형상을 관찰하고 병소의 깊이를 측정하였다.

병소의 깊이는 치면열구전색제 변연 $20 \mu \mathrm{m}$ 하방의 깊이를 기준으로 측정하였다.

\section{6) 통계분석}

통계 분석은 SPSS 17.0 (SPSS Inc., Chicago, IL, USA) 을 이용하여 미세노출의 정도는 Chi-square test를, 측정된 우 식의 깊이는 Mann-Whitney test를 이용해 두 군간의 유의성을 검증하였다. 각 통계 방법은 $95 \%$ 의 유의 수준을 사용하였다.

\section{III. 연구 성적}

\section{1. 미세누출의 실험}

유동성레진 치면열구전색제의 경우 침투가 관찰되지 않은 시 편은 16 개, 열구 $1 / 2$ 이내에 침투가 관찰된 시편은 2 개, $1 / 2$ 이상 침투가 관찰된 시편은 1 개, 열구 하방 까지 침투가 관찰된 경우는 1 개 였으며, S-PRG 치면열구전색제의 경우 침투가 관 찰되지 않은 시편은 15 개, 열구 $1 / 2$ 이내에 침투가 관찰된 시 편은 1 개, $1 / 2$ 이상 침투가 관찰된 시편은 2 개, 열구 하방 까지 침투가 관찰된 경우는 2 개였다(Fig. 1). 두 군 사이에 통계학적 유의한 차이는 관찰되지 않았다(Table 3$)(p<0.05)$.

\section{2. 항우식 효과의 평가}

각 군의 우식병소 양상을 편광현미경으로 관찰해본 결과 $\mathrm{S}-$ $\mathrm{PRG}$ 치면열구전색제 주위에 국한된 적은 병소 깊이를 관찰할 수 있었으나, 유동성레진 치면열구전색제는 일정한 병소의 깊 이가 관찰되었다(Fig. 2). S-PRG 치면열구전색제 변연의 병
소 깊이는 $30.5 \pm 2.0 \mu \mathrm{m}$, 유동성레진 치면열구전색제는 $70.8 \pm 5.1 \mu \mathrm{m}$ 였으며 둘 사이에는 통계학적으로 유의한 차이 $(p<0.05)$ 를 보였다(Table 4$)$.

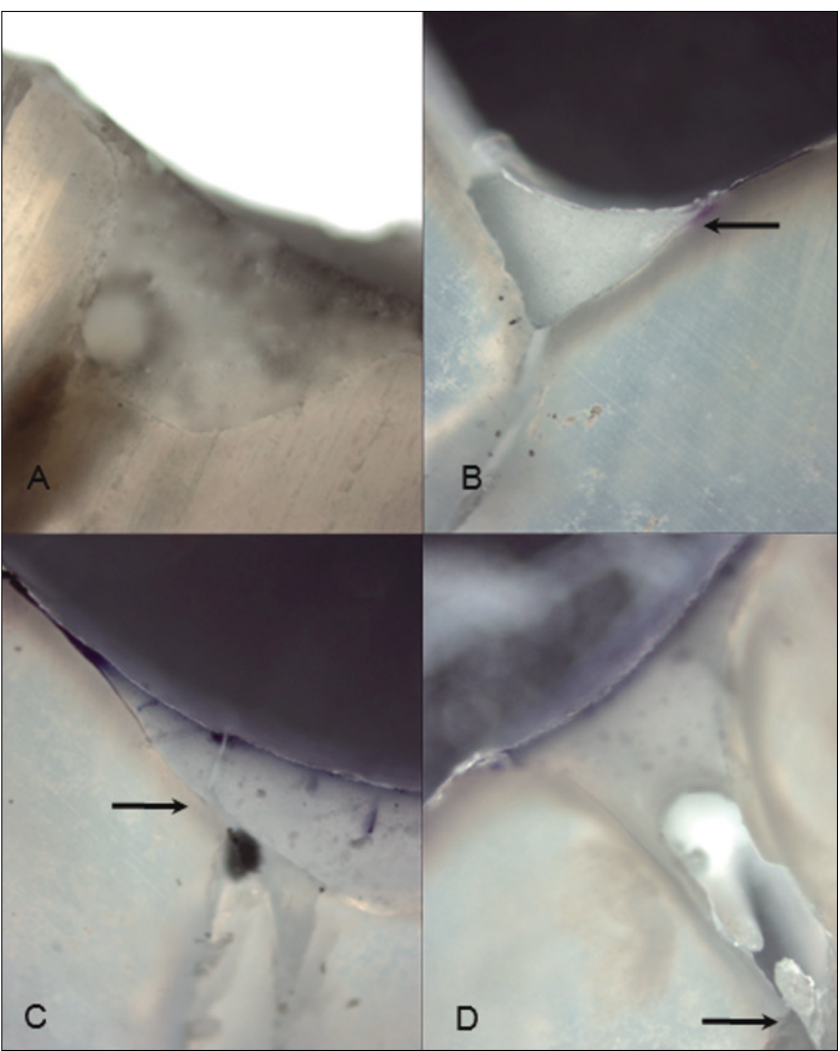

Fig 1. Samples of each marginal seal score after dye immerse. A. Score $0(\times 100)$, B. Score - $2(\times 100)$, C. Score - $3(\times 100)$, D. Score $-(\times 100)$.

Table 3. Distribution of microleakage

\begin{tabular}{lcccc}
\hline & 0 & 1 & 2 & 3 \\
\hline Flowable resin sealant & 16 & 2 & 1 & 1 \\
S-PRG sealant & 15 & 1 & 2 & 2 \\
\hline
\end{tabular}

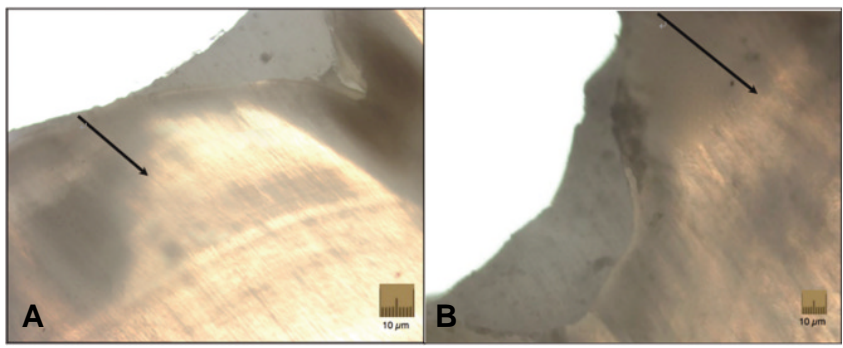

Fig. 2. Polarizing microscope image of caries. A. S-PRG sealant, B. Flowable resin sealant $(\times 100)$.

Table 4. Mean depth of caries lesion

\begin{tabular}{ll}
\hline & Depth of lesion \\
\hline Flowable resin sealant & $70.8 \pm 5.1 \mu \mathrm{m}$ \\
S-PRG sealant & $30.5 \pm 2.0 \mu \mathrm{m}$ \\
\hline
\end{tabular}




\section{IV. 총괄 및 고찰}

치면열구전색시 별도의 유지구를 형성 해주지는 않기 때문에 치면열구전색제는 교합력, 마모, 습도의 변화에 쉽게 영향을 받 아 통상적인 수복물에 비해 탈락률이 높다. 또한 불완전한 치면 열구전색은 이차 우식을 유발하는데 이러한 이차 우식은 수복 물 실패의 가장 흔한 원인 요소이며 ${ }^{17)}$, 특히 구강위생관리 능력 에 한계가 있는 소아환자의 경우에는 그 빈도가 더욱 높은 것으 로 알려져 있다 ${ }^{12)}$. 이러한 문제를 극복하고자 유지율의 증가와 전색제 탈락 후 열구 내 치질의 내산성 증가 노력의 일환으로 불소를 첨가해 항우식 효과를 증진시키려는 시도가 계속 되었 다. 그 결과물로 컴포머와 레진 광화형 글라스아이오너머가 나 왔으나, 컴포머의 물성, 불소 유리 두 가지 모두에서 만족할 만 한 결과를 보여주지 못하였고, 레진 광화형 글라스 아이오너머 도 물리적 한계로 인해 임상에서의 사용이 제한적이다 ${ }^{14)}$.

Beautisealant ${ }^{\mathbb{\circledR}}$ 는 Robert 등히 이 개발한 S-PRG 필러기술 을 이용한 새로운 충전 재료인 자이오머 실란트이다. 레진 기질 에 S-PRG 필러를 함유시킴으로써 복합 레진의 심미성과 물성 을 가지고 있고 글라스아이오노머의 장점인 불소 유리 능력도 있다고 한다.

Ying 등(1)과 Shimazu 등 ${ }^{19}$ 의 연구를 보면 자이오머가 불소 를 유리한다는 사실을 알 수 있지만 실제 임상에서 이러한 불소 의 유리가 항우식효과를 가져올지에 대한 의구심에 본 연구를 시행하였다.

수복재의 항우식효과를 확인하기 위해서는 일반적으로 인위 적인 우식병소의 유발이 필요한데 이런 우식 병소는 자연병소 와 구조적으로 유사하며 균일하고 재현성이 있어야 한다 ${ }^{20)}$. 인 공 우식 병소를 유발시키는 방법에는 여러가지가 있으나 본 실 험에서 사용한 우식용액은 1987 년 White 등'6)이 합성 폴리머 젤을 이용해 만든 것으로 효과적으로 건전 표층을 유지하면서, 균질의 조직학적 형태와 병소 깊이 조절이 가능한 인공 우식 유 발 용액이다.

Carbopol $^{\circledR}$ 907을 이용한 인공우식 용액은 탈회 9일 후 약 $80 \mu \mathrm{m}$ 라는 두드러지게 깊은 병소깊이를 보여 ${ }^{16)}$ 본 연구에서는 치아 시편을 인공우식용액에 9일간 보관하였다.

치면열구전색제 변연 $20 \mu \mathrm{m}$ 하방의 깊이가 S-PRG 치면열 구전색제는 $30.5 \pm 2.0 \mu \mathrm{m}$, 유동성레진 치면열구전색제는 $70.8 \pm 5.1 \mu \mathrm{m}$ 의 깊이를 보였다. White ${ }^{15)}$ 등의 실험에서 인 공우식 용액에 치아를 적용했을 때 약 $80 \mu \mathrm{m}$ 의 깊이를 보인데 반해 본 실험에서는 약 $70 \mu \mathrm{m}$ 의 인공우식 병소 깊이가 관찰되 었다. 유동성레진 치면열구전색제의 우식 병소 깊이가 불소 유 리가 전혀 없음에도 얕은것으로 보아 이는 치면열구전색제의 항우식효과와 상관없이 치면열구전색제가 물리적 장벽으로서 역할을 하고 있기 때문으로 생각된다.

또한 두 재료간에 우식의 양상 차이가 관찰되었는데 S-PRG 치면열구전색제의 경우 치면열구전색제에서 멀어질수록 우식의 깊이가 증가하다 일정해지는 양상을 보인데 반해 유동성레진 치면열구전색제의 경우는 치면열구전색제로부터의 거리와 상관
없이 일정한 깊이의 우식병소가 관찰되었다. 이러한 양상의 차 이는 S-PRG 필러에서 유리된 불소가 항우식용액에 의해 탈회 된 인접 법랑질의 재광화를 촉진해 이러한 항우식효과가 나타 났다고 생각된다.

이 외에도 S-PRG 필러에서는 스트론튬이온이 유리되는데 스 트론튬은 치아 법랑질의 광화에 중요한 역할을 하며 ${ }^{21)}$, 최근의 연구에 따르면 스트론튬은 불소와 상호작용을 통해 치아 법랑질 재광화효과를 증대시켜 치아의 탈회를 감소시킨다고한다 ${ }^{22)}$.

미세누출 점수 0 을 기준으로 미세누출을 비교 해 보면, Ganesh 등 ${ }^{23}$ 이 시행한 실험에서는 $45 \%, \operatorname{Lim}$ 등 $^{24)}$ 이 시행한 실험에서는 $70 \%$ 의 실험결과를 보였다. 본 실험에서는 $80 \%$ 로 다른 실험에 비해 더 높은 성공률을 보였는데 이는 아마도 주변 의 실험 환경과 실란트 적용 후 광중합을 시행하기 전에 추가적 으로 탐침을 사용해 열구 깊이 치면열구전색제를 적합하고, 면 봉을 이용해 과잉의 치면열구전색제를 제거한 기술적인 요소에 그 차이가 있는 게 아닌 가 생각된다. 이러한 탐침의 사용은 실 험 결과의 차이를 유발할 수 있지만 본 실험에서는 두 군 모두 에서 다음의 과정을 시행했기에 실험 결과의 유의성 평가에 큰 영향을 주진 않았을 것으로 사료된다.

필러 함량의 증가는 수복물의 점도를 증가시키는데 이러한 점도의 증가는 수복물의 침투도를 떨어뜨리며 이는 수복물의 미세누출을 증가시키는 결과를 가져온다. 유동성레진 치면열구 전색제의 경우는 필러의 함량이 적은데 반해 S-PRG 치면열구 전색제는 S-PRG 필러를 함유하고 있기 때문에 미세누출 결과 가 차이가 날 것으로 예상했지만 본 실험에서는 두 재료간의 유 의한 차이는 관찰되지 않았다. 이는 S-PRG 치면열구전색제에 사용되는 프라이머가 치면열구전색제의 침투와 치면과의 결합 을 돕기 때문이 아닐까 생각된다.

항우식효과를 평가하는 방법은 탈회 깊이 측정 외에도 치면 열구전색제 인접 법랑질의 무기물의 조성변화, 경도변화, 불소 침투깊이 측정 등이 있는데 다음 연구에서는 좀 더 다각적인 분 석이 추가적으로 필요하다고 생각된다.

\section{V. 결 론}

S-PRG 치면열구전색제와 유동성레진 치면열구전색제의 변 연봉쇄성과 항우식효과를 조사한 결과, 다음과 같은 결론을 얻 을 수 있었다.

S-PRG 치면열구전색제의 75\%, 유동성레진 치면열구전색 제의 $80 \%$ 에서 미세누출이 일어나지 않았으며 두 군사이에 통 계학적으로 유의한 차이는 관찰되지 않았다 $(p>0.05)$. 하지만 우식의 깊이는 S-PRG 치면열구전색제를 적용한 법랑질에서는 $30.5 \pm 2.0 \mu \mathrm{m}$, 유동성레진 치면열구전색제를 적용한 법랑질 에서는 $70.8 \pm 5.1 \mu \mathrm{m}$ 를 보였으며 이는 통계학적으로도 유의 한 차이를 보였다 $(p<0.05)$. 


\section{References}

1. Beauchamp J, Caufield PW, Crall JJ : Evidencebased Clinical Recommendations for the use of Pitand-fissure Sealants: A Report of the American Dental Association Council on Scientific Affairs. $J$ Am Dent Assoc, 139:257-68, 2008.

2. Feigal RJ, Donly KJ : The use of pit and fissure sealants. Pediatr Dent, 28:143-50, 2006.

3. Cueto EI, Buonocore MG : Sealing of pits and fissures with an adhesive resin: its use in caries prevention. J Am Dent Assoc, 75:121-128, 1967.

4. Gwinnett AJ, Ripa LW : Penetration of pit and fissure sealants into conditioned human enamel in vivo. Arch Oral Biol, 18:435-439, 1973.

5. Hyatt TP : Occlusal fissures: Their frequency and danger. How shall they be treated? Dent Items Interest, 46:493, 1924.

6. Bodecker CF : The eradication of enamel fissures. Dent Items Interest, 51:859, 1929.

7. Bowen RL : Composite and sealant resin-past, present and future. Pediatric Dent, 4:10, 1982.

8. Benelli Em, Serra MC, Rodrigues Al Jr., Cury JA : In situ anticariogenic potential od glass ionomer cement. Caries Res, 27:280-284, 1993.

9. Qvist V, Laurberg L, Poulsen A, Teglers PT : Eightyear study on conventional glass ionomer and amalgam restorations in primary teeth. Acta Odontol Scand, 62:37-45, 2004.

10. Berg JH, Donly KJ, Posnick WR : Glass ionomer-silver restorations: a demineralization-remineralization concept. Quintessence Int, 19:639-641, 1988.

11. Derkson GD, Richardson AS, Jinks GM : Clinical evaluation of a restoration containing fluoride: twoyear results. Pediatr Dent, 11:286-290, 1989.

12. Berg JH : The continuum of restorative materials in pediatric dentistry, A review for the clinician. Pediatr Dent, 20:93-100, 1998.

13. Roberts TA, Miyai K, Ikemura K : Fluoride ion sus- tained release preformed glass ionomer filler and dental compositions containing the same. United States Patent No.5883153, 1999.

14. Kim JS : Compressive strength and microhardness of flowable composite resin and flowable giomer. $J$ Korean Acad Pediatr Dent, 39:383-388, 2012.

15. Ovrebo RC : Microleakage in fissures sealed with resin or glass ionomer cement. Scand. J Dent Res, 98:66-69, 1990.

16. White DJ : Use of synthetic polymergels for artificial carious lesion preparation. Caries Res, 21:228-242, 1987.

17. Mjor IA : Frequency of secondary caries at various anatomical locations. Oper Dent, 10:88-92, 1985.

18. Wang Y, Kaga M : In release and buffering capacity of S-PRG filler-containing pit and fissure sealant in lactic acid. Nano Biomedicine, 3:275-281, 2011.

19. Shimaz K : Evaluation of the ion-releasing and recharging abilities of a resin-based fissure sealant containing S-PRG filler. Dental material journal, 30:923-927, 2011.

20. Arends J, Bousch JJ : Demineralization and remineralization evaluation techniques. J Dent Res, 71:924-928, 1992

21. Mishima H, Kozawa Y : SEM and EDS analysis of calcospherites in human teeth. Eur J Oral Sci, 106:392-296, 1998.

22. Thuy TT, Nakagaki H, Robinson C, et al. : Effect of strontium in combination with fluoride on enamel remineralization in vitro. Arch Oral Biol, 53:10171022, 2008.

23. Ganesh M : Comparative evaluation of the marginal sealing ability of fuji vii and concise as pit and fissure sealants. $J$ contemporary dental practice, 4:1018, 2007.

24. Im E : A study of microleakeage and penetration ability of a pit and fissure sealant applied on carious fissures. J Korean Acad Pediatr Dent, 37:345-351, 2010. 
국문초록

\title{
S-PRG filler를 함유한 치면열구전색제의 미세누출 및 항우식효과
}

\author{
신승우 · 김종수
}

단국대학교 치과대학 소아치과학교실

치면열구전색은 생물막의 축적을 물리적으로 막아주며 박테리아에 의해 형성되는 산물질에 화학적 장벽 역할을 한다. 1999년 S-PRG(Surface reaction-type pre-reacted glass ionomer) 필러기술이 개발되었는데 S-PRG 필러는 수분 존재 하에서 스스로 분해되지 않으면서, 지속적으로 불소유리가 가능하다. 이에 저자는S-PRG 필러를 포함하는 치면열구전색제 의 미세누출 및 인접 법랑질에 대한 항우식 효과를 기존의 유동성레진 치면열구전색제와 비교해 보고자 한다.

건전한 소구치, 대구치를 실험 대상으로 사용하였다. S-PRG 필러를 함유해 불소를 유리하는 치면열구전색제 Beautisealant ${ }^{\circledR}$ (Shofu, Japan)를 실험군으로, 유동성레진 치면열구전색제 Concise $^{\circledR}$ (3M ESPE, USA)를 대조군으로 선 정하였다. 미세누출실험을 위해 실란트 변연 $1 \mathrm{~mm}$ 를 제외한 나머지 치아에 손톱광택제를 2 회 도포 후 $2 \%$ 메틸렌블루 용액 에 24시간 동안 보관 후 수세하였다. 항우식효과의 평가는 인공우식용액에 9일간 보관 후 수세 후 시행하였다. 수세한 시편 들은 투명레진에 매립 후 현미경 관찰을 위해 절단하였다. 통계분석은 미세노출의 정도는 Chisquare test를, 측정된 우식의 깊이는 Mann-Whitney test를 이용해 두 군 간의 유의성을 검증하였다.

S-PRG 치면열구전색제와 유동성레진 치면열구전색제의 미세누출 차이는 관찰되지 않았지만, S-PRG 치면열구전색제는 유동성레진 치면열구전색제 보다 더 높은 항우식효과를 보이는 것으로 나타났다.

주요어: S-PRG 필러, 자이오머, 항우식 효과, 미세누출 